УДК 351.712

DOI: https://doi.org/10.26642/jen-2019-3(89)-165-173

\author{
В.Ф. Загурська-Антонюк, к.політ.н. \\ С.А. Березенська, магістрант \\ Т.П. Вовкотруб, магістрант \\ О.В. Бондаренко, магістрант \\ Державний університет «Житомирська політехніка»
}

\title{
Підвищення ефективності роботи та кар'єрного потенціалу державних службовців в Україні
}

\begin{abstract}
У ціий статті розглядаються механізми та можливості підвищення ефективності роботи державних службовців $i$ фахівців органів місцевого самоврядування в умовах розбудови інноваційно-інвестиційної моделі розвитку Украӥни. Адже політична та соціально-економічна трансформачія українського суспільства посилює вимоги до діяльності органів державного управління, вимагає підвищення ефективності та результативності діяльності інституту державної служби. Саме на цей інститут покладено завдання зміцнення украӥнськоі державності ци розвитку демократичного суспільства, управління економічною, адміністративно-політичною, сочіально-культурною сферами, проведення в країні реформ. Детерміновані фактори, які впливають на ефективність діяльності державних службовців, а також визначені основні показники для оцінки ефективності діяльності держслужбовия.

Політична та економічна напруженість у державі посилює вимоги до сучасного державного управління, ефективність якого залежить, передусім, від ефективної державної служби. Висока плинність кадрів, особливо молодих і висококваліфікованих спеціалістів, низька продуктивність та якість прийняття рімень в органах виконавчої влади є наслідками неефективної діяльності державних службовців, щзо негативно впливає на результативність діяльності державної служби в иілому. Тому одним із иляхів досягнення високої ефективності функціонування органів державного управління є використання функиї̈ мотивації, щчо дозволить підвищити зацікавленість у державних службовців працџювати ініціативно та активно, розкривати та реалізовувати свій трудовий потенціал задля держави та служіння народу Украӥни. Тому планування кар'єри державного службовия передбачає визначення засобів для досягнення бажаних результатів. Відповідальність за виконання планових заходів лежить як на організації, так і на працівникові. При цъьому керівники підрозділів мають надавати своїм працівникам інформацію про потреби і можливості державної установи (органу державного управління) у кадровому забезпеченні не тільки у межах свого підрозділу, а й по державній установі в иілому.

Ключові слова: державний службовець; ефективна діяльність держслужбовця; кар'єрний потенціал; механізми управління; місиеве самоврядування; органи державної влади; показники оиінки діяльності держслужби; регулювання; управління кар'єрним потенціалом; фактори впливу на діяльність держслужбовия.
\end{abstract}

Постановка проблеми. На сучасному етапі державотворення в Україні, коли все гостріше відчувається необхідність підготовки нової генерації висококваліфікованих державних службовців, спроможних ефективно і в найкоротші строки реалізувати в країні реформи, значно підвищується роль менеджменту людських ресурсів в органах виконавчої влади. Адже нові кадри потребують нових підходів до їхнього управління. Саме тому в останні роки активізувалися наукові дослідження у напрямі розробки ефективних механізмів формування та реалізації системи управління персоналом на державній службі.

Політична та економічна напруженість у державі посилює вимоги до сучасного державного управління, ефективність якого залежить, передусім, від ефективної державної служби. Висока плинність кадрів, особливо молодих і висококваліфікованих спеціалістів, низька продуктивність та якість прийняття рішень в органах виконавчої влади $є$ наслідками неефективної діяльності державних службовців, що негативно впливає на результативність діяльності державної служби в цілому. Тому одним зі шляхів досягнення високої ефективності функціонування органів державного управління $€$ використання функції мотивації, що дозволить підвищити зацікавленість у державних службовців працювати ініціативно та активно, розкривати та реалізовувати свій трудовий потенціал задля держави та служіння народу України.

Аналіз останніх досліджень і публікацій. В останні роки 3'явилося багато наукових досліджень стосовно ролі і місця державних службовців в умовах перманентної кризи державного управління i шляхів його вдосконалення. Значне місце в цих роботах займають питання кар'єри, професійної 
діяльності та мотивації державних службовців. 3'явилися цікаві наукові праці і дослідження з цих питань відомих вітчизняних фахівців: Біскупа В., Бондаря В., Буцької Т., Виногородського М., Ігнат'єва П., Князєва В., Крушельницької О., Лугового В., Малиновського В., Мостового Г., Мельничука Д., Мокренка Т., Ніжник Н., Рибкало В. Також цією тематикою займалися зарубіжні фахівці: Армстронг М., Стефан П. Робінс, Девід А. де Ченцо, Сгоршін А., Патрушев В., Попов Г., Пригожин А., Романов В. та інші.

Незважаючи на значні публікації і здобутки в сфері комплексного, міждисциплінарного дослідження теорії кар'єри держслужбовця в науковій літературі, ще й досі чітко не визначені поняття «кар'єра», «управління кар'єрою», «кар'єрний потенціал державного службовця (управлінця)», «управління кар'єрним потенціалом». Як показують українські дослідження, вітчизняна наука та практика ще не виробила необхідний теоретично-практичний матеріал для створення ефективного механізму управління кар'єрою державного службовця - як важливої складової реформи Державної служби України. Таким чином, невирішеність проблеми стосовно сутності системи управління кар'єрою, факторів, що впливають на ефективність іiі функціонування, а також оцінки кар'єрного потенціалу державного службовця зумовили необхідність подальшого дослідження цієї складової теми.

Постановка завдань. Одним із завдань адміністративної реформи в Україні є забезпечення високої ефективності державного управління, а ця ефективність значною мірою залежить від державних службовців, якщо розглядати державне управління як діяльність, що здійснюється людьми, стосовно людей і винятково в їх інтересах. Відомо, що ефективність державного управління тісно пов'язана 3 ефективністю діяльності державних службовців. Організація системи державної служби в Україні на сьогодні має багато недоліків, і в першу чергу, в питаннях найму, просування по службі, досягнення необхідного рівня кваліфікації, рівня корупції та мотивації державних службовців.

Тому метою цієї статті є визначення поняття «ефективності», механізмів та умов іï формування i реалізації, їі складових та ролі, яку вона відіграє у якості роботи державних службовців та їх кар'єрного зростання.

Для цього необхідно реалізувати такі завдання: на основі наукової літератури дати визначення ефективності роботи державних службовців відповідно до нових сучасних реалій; виявити складові компоненти ефективності; визначити, яку роль вона відіграє в процесі підвищення професійної компетентності та кар'єрного зростання державних службовців.

Викладення основного матеріалу. Ефективність роботи будь-якої організації залежить не лише від якісно розроблених планів та організації роботи, а, перш за все, від самих людей, їх трудового потенціалу, працездатності, ініціативності та наполегливості в реалізації цих планів; від професійної компетентності та ділової активності, прагнення до самовдосконалення та самореалізації державних службовців залежать результати роботи органу державного управління.

У теорії існують дві основні моделі державної служби: кар'єрна (закрита) і посадова (відкрита). Особливістю кар'єрної державної служби є те, що кандидат вступає на службу, займаючи нижчу посаду в чітко визначеній кар'єрній ієрархії. Зазвичай, прихід на державну службу після певного навчання - це призначення на все життя. Кар'єрна модель потребує досить вузької професійної підготовки, а досвід роботи розглядається як найбільш важливий показник набуття кваліфікації. У посадовій системі посади розглядають як у приватному секторі, їх систематизують на основі кваліфікаційних вимог. Для державних службовців у такій моделі привілеї виражено в конкурентній на ринку праці заробітній платі, а перевагу віддають так званим «універсальним» державним службовцям - фахівцям з питань управління 3 достатньо широким спектром знань і вмінь.

Нині досить поширеною є практика застосування комбінування типових елементів, характерних для зазначених вище моделей. Досвід європейських країн показує, що жодна країна не застосовує одну 3 двох моделей у чистому вигляді. Зважаючи на це, вивчення світового досвіду, а також набуття та вдосконалення власного, має стати одним з пріоритетних завдань управлінської науки. Як зазначають українські дослідники, у вітчизняній практиці в системі роботи з персоналом в державних установах та на підприємствах, відсутня така підсистема, як «управління кар'єрою», немає механізму, який би дозволив відстежити, наскільки повно реалізуються кар'єрні можливості того або іншого працівника. Актуальність цієї теми посилюється ще й 3 врахуванням євроінтегральних прагнень України, адже реформування національної державної служби має відбуватись із врахуванням досвіду ефективності державної служби в країнах ЄС. Актуальною перспективою професійного формування особистості державного службовця та його самореалізації на державній службі є розвиток кар'єрних нахилів. Успішно спланований та вдало реалізований план проходження по соціальних сходинках є запорукою добробуту людини та ефективного функціонування державної установи. У вітчизняній науковій літературі донедавна поняття «кар'єра» практично не використовувалося і недостатньо досліджувалося, ставлення до кар'єри з боку суспільства було досить негативне і асоціювалося 3 таким явищем. як кар'єризм, тому спочатку дамо класичне визначення «кар'єри». Отже, кар'єра (італ. carriera - дія, життєвий шлях, від лат. carrus - віз, візок) - швидке й успішне просування по службовій, суспільній, науковій та іншій діяльності, досягнення популярності, вигоди, рід діяльності [1, с. 314]. Кар'єра (від 
франц. carriete) - це професійний шлях до успіху, до престижного соціального статусу і положення у суспільстві. У словнику Ожегова С. це слово характеризується таким чином: рід занять, діяльності; шлях до успіхів, вигідне становище у суспільстві, у службовій діяльності, а також саме досягнення такого положення [2, с. 247].

Кар'єра у системі конкурентноздатності державного службовця (управлінця) є складним об'єктом наукового аналізу, який належить до комплексних міждисциплінарних категорій і вимагає використання різних підходів, особливо соціально-економічного та психологічного. Багатогранність теми дослідження вимагає перш за все аналізу концепцій вітчизняних та зарубіжних учених 3 проблем психологічної соціалізації та креативної самоактуалізації державних службовців, їх зацікавленості у кар'єрному зростанні. Кар'єра як процес і результат внутрішньо вмотивованого та індивідуально визначеного особистісного шляху, об'єктивно є багаторівневим і структурно розгалуженим феноменом соціального життя. Можливість самореалізації, задоволення потреби в самоповазі й самоактуалізації, побудова свого життя відповідно до своїх прагнень знаходяться у тісному зв'язку з культурними, економічними, політичними умовами, в яких перебуває конкретна особистість [3, с. 2]. Якщо узагальнити підходи, які напрацьовані в науковій літературі, то в більшості випадків кар'єру визначають як траєкторію руху людини, яку вона створює сама, враховуючи особливості внутрішнього і зовнішнього середовища, реальність, власні цілі, бажання і здібності [4, с. 158]. За визначенням науковців, кар'єра - це індивідуальні зміни позиції та поведінки, які пов'язані з досвідом роботи і всієї трудової діяльності людини [5, с. 347]. Найбільш популярне визначення кар'єри це є: одержання більшої кількості грошей, більших повноважень, більш високого статусу, більш високого престижу, найвищої влади. Отже, змістовною складовою поняття «кар'єри» є просування, тобто рух вперед. Використовуються і такі поняття, як зростання, досягнення, перехід та інші. Тобто, кар'єра - це процес, який визначається як проходження, послідовність зміни робочого стану людини, тобто тут розглядається не як статистичний, стабільний стан, а як процес зміни подій, як активне просування людини в освоєнні та вдосконаленні способів життєдіяльності. Тип кар'єрного процесу дає уявлення про особливості його виникнення, спрямованості та внутрішньої організованості, зовнішніх зв'язках, взаємодіях відносно інших процесів [5, с. 348]. Кар'єра у цьому сенсі постає не просто як просування індивіда у соціальному просторі, послідовна зміна позицій у ньому, а як використання набутого найоптимальнішим чином культурного, освітнього, професійного капіталу за умови стрімкої зміни вимог і зростаючої конкуренції у професійній діяльності. У соціальній психології та психології професійної діяльності поняття «кар'єра» розглядається як соціальна динаміка розвитку особистості та їі поведінкових проявів, що пов'язані 3 досвідом та активністю у сфері праці протягом людського життя [6, с. 9].

У науковій психологічній літературі поняття «кар'єра» трактується як:

1) вид професійної діяльності на окремих етапах трудового шляху людини;

2) професійний ріст і накопичення майстерності, професійних знань і активної життєвої позиції протягом робочого життя людини;

3) види діяльності, поєднані зі способом життя, які реалізують життєві цілі;

4) як професійний досвід конкретної людини, що стосується не тільки професії;

5) праця, робота, служба; посада; професія-покликання із включенням як службової, так i неслужбової діяльності, яка свідомо підкоряється досягненню певної мети.

Поряд 3 цими властивими якостями кар'єри, виокремлюються і такі її види: прогресивний (розвиток по висхідній); регресивний (розвиток зі спадами і низхідним рухом); лінійний (безперервний, послідовний процес розвитку кар'єри); нелінійний (наявність стрибків, перерв та проривів); спіралеподібний (схожі процеси кар'єрних ротацій здійснюються на різних ієрархічних рівнях); стагнаційний (застій, коли тривалий час немає змін ані в посаді, ані в зарплатні). Зауважено, що кар'єра це не завжди влада, багатство чи просування по службі, але це завжди успіх, це завжди ріст: творчий, професійний, службовий чи просто економічний - у вигляді підвищення заробітної плати [6, с. 3].

На думку деяких дослідників, кар'єра - це своєрідний турнір, пов'язаний з успіхами і невдачами, які можуть серйозно вплинути на подальший хід кар'єрного росту людини, зокрема, державного службовця. Інакше кажучи, чим довше людина знаходиться на першому щаблі кар'єрних сходів, тим менше у неї можливостей для прогресу. Традиційно під кар'єрою розумілося просування по службових сходинах певної організації. Зазвичай, людина, обравши професію, намагалася знайти організацію, у якій іiі праця могла бути цілковито затребувана. Організація зі свого боку надавала їй можливість кар'єрного росту. Вибравши одне одного, організація та людина укладали «психологічний» контракт, що припускав гарантію зайнятості й можливості професійного та кар'єрного росту з боку організації, а 3 боку співробітника - обов'язковий прояв відданості організації.

Гендерні дослідження наочно продемонстрували статеві відмінності інтересів, спрямування, професійних виборів і типів кар'єр, кар'єрних досягнень, поведінки на роботі, поєднання ролей професійних 3 іншими життєвими ролями. У цьому напрямі американський дослідник Д.Сьюпер запропонував одну з перших психологічних класифікацій кар’єр. У ній вирізнено чоловічі та жіночі типи 
кар'єр залежно від чергування професійних проб і періодів стабільної роботи [7, с. 3]. Чоловічі типи кар'єр - це:

стабільна кар'єра, коли суб'єкт відразу після навчання займається професійною діяльністю і незмінно слідує обраному шляху; звичайна кар'єра, коли після навчання відбувається серія професійних спроб, які закінчуються стабільною службою;

- нестабільна - 3 чергуванням професійних спроб і періодів стабільної роботи; кар'єра із множиною спроб, коли людина часто змінює вид діяльності, не маючи стабільної роботи.

Жіночі типи кар'єр більш різноманітні - це:

- кар'єра домогосподарки;

- звичайна кар'єра, коли жінки, які мають освіту, виходять заміж, припиняють працювати та стають домогосподарками;

- стабільна робоча кар'єра, коли здобута освіта допомагає знайти роботу, що стає справою життя;

- дволінійна кар'єра, коли кар'єра домогосподарки співіснує зі стабільною робочою кар'єрою;

- $\quad$ переривчаста кар'єра - робота до одруження, потім перерва (народження та виховання дітей), повернення на роботу;

- $\quad$ нестабільна кар'єра - чергування періодів роботи після одруження поряд 3 поверненням до кар'єри домогосподарки;

- $\quad$ кар'єра 3 множинними спробами - послідовність непов'язаних видів праці без стабілізації у якій-небудь професійній галузі [6, с. 356].

Дослідником А.Сгоршиним виокремлено чотири види типових кар'єр, а саме:

а) «роздоріжжя»- характерним є для молодих спеціалістів, які мають зробити вибір між гарантією місця роботи та особистою свободою; це вибір сенсу роботи, життєвого кредо, напряму дій;

б) «змія» - поєднання кар'єри спеціаліста у своїй справі та лінійного керівника, при цьому потенційно висококваліфіковані професіонали не затримуються на одній посаді більше 2-3 років;

в) «драбина» - кожну посаду на шляху просування працівник займає приблизно однаковий термін часу;

г) «трамплін» - стрибок у пенсійний стан і консультаційну діяльність, при цьому послідовне проходження сходин тут необов'язкове. [8, с. 98-105; 9, с. 125].

Аналіз наукових праць дозволяє стверджувати про наявність трьох напрямів кар'єри, у тому числі: 1) професійний - враховує навчання, професійне зростання, підвищення кваліфікації працівника; 2) внутрішньо організаційний - реалізується у середині організації і має два види: вертикальний та горизонтальний. При цьому також існує особливе просування - доцентрове, рух до верхівки влади; 3) організаційний - просування реалізується шляхом зміни роботи, переходом до іншої установи, що характерним $є$ за умов економічної кризи.

Сучасний стан розуміння професійної кар'єри має свої особливості. В останні роки радикально змінилися уявлення про кар'єру. Тепер це поняття дозволяє людині осмислювати свій професійний розвиток, оцінюючи професійний досвід, використовувати його резерви для реалістичного розуміння власних можливостей.

У дослідженні С.Орстейна та Л.Ізабелли зазначено, що звичні уявлення про кар'єру розвиваються в аспекті інтересів не стільки організації, скільки їі співробітників. Велике значення тут має суб'єктивність розуміння ними ресурсів кар'єрного росту [10, с. 664]. Уявлення про кар'єру раніше визначалося стабільністю положення на ринку і структурою організації, ієрархія якої надавала можливість просування співробітників багаторівневими службовими сходами. Визначений рівень мав відповідати певному віку співробітника.

За останні роки, у зв'язку з радикально зміненим становищем на ринку праці, змінилися і можливості досягнення кар'єри та уявлення про неї. Якщо раніше умови кар'єри диктувалися внутрішнім ринком праці і припускали повну довгострокову, гарантовану зайнятість, регулярність і передбачуваність просування, відданість професії та організації, то тепер умови визначає ринок зовнішній. Стало характерним укладання тимчасових контрактів, неповна зайнятість, часткові зміни в кар'єрі, зайнятість у декількох сферах діяльності й у декількох організаціях, непередбачуваність трудових переміщень, самоуправління кар'єрою. Останнім часом змінилися обставини у сфері професійної зайнятості. Якщо раніше вона відрізнялася стабільністю, гарантованістю, довготривалістю, то тепер їй притаманні тимчасовий характер контрактів, відсутність стабільних гарантій, непередбачуваність, самоконтроль і самостійне управління своєю кар'єрою.

Важливо зрозуміти, які фактори та яким чином впливають на кар’єрні установки й наміри державного службовця. Це корисно для нього і як співробітника певного державного органу виконавчої влади, і як особистості, яка розвивається. Тим більше, це важливо і для самої установи, зацікавленої у плануванні ефективної стратегії управління кар'єрою і професійному розвитку своїх співробітників. Іншими словами, 
потрібна регуляція відносин організації і співробітників з метою задоволення інтересів учасників ділових відносин. В умовах сучасного менеджменту персоналу і реальної дійсності державних установ необхідна системна кар'єра. В органах державної служби відсутня так звана система управління кар'єрою. Немає відповідної методичної бази, а також загальноприйнятих понять про кар'єру. Все це вимагає наукових психологічних розробок як у теорії, так і в сфері практичного застосування знань [11, с. 19].

3 кар'єрою пов'язані будь-які переміщення персоналу. Не всі з них можна запланувати, наприклад, за наявності ситуаційно обумовлених чинників. Уявлення ж про кар'єру постійно зазнають змін, дозволяючи окремій людині осмислювати свій професійний розвиток, порівнюючи власний теперішній $і$ минулий досвід, реально оцінювати свої можливості у майбутньому. Тепер «психологічний контакт» може переглядатися у зв'язку зі зміною обставин з тієї чи іншої сторони, наприклад, при переході на іншу стадію професійного розвитку. Отже, кар'єру можна розглядати як постійний і послідовний перегляд «психологічних контактів». Саме тому, вивчення розвитку кар'єри означає вивчення індивіда, що розвивається у постійно змінних і складних умовах середовища, під впливом соціальної ситуації.

Аналіз наукових джерел 3 питань державного управління засвідчує універсалізацію підходу до визначення кар'єри державного службовця. Кар'єру розуміють як поступове просування працівника службовими сходинками, зміну кваліфікаційних можливостей, навичок, здібностей, розмірів винагород, пов'язаних з його діяльністю [12, с. 104]. Взагалі, сьогодні в умовах дуже частої перманентної зміни державних службовців на посадах ситуація 3 кар'єрою державного службовця є складною і мало привабливою $\mathrm{i}$ це підтверджують різноманітні соціологічні дослідження. Зокрема, опитування серед державних службовців на тему: «Чи задоволені вони своїм кар'єрним становищем?», - засвідчило, що близько 55 відсотків респондентів повністю або частково незадоволені і прагнуть до реалізації мотиву влади $[13$, с. 430]. Підтверджує цю думку І.Буцька, яка зазначає, що на сьогодні для більшості державних службовців кар'єра є не результатом реалізації довгострокового плану, а набір випадків [14, с. 86]. На думку С.Серьогіна, кар’єру в сфері державного управління можна охарактеризувати так, що це не тільки досягнення більш високого посадового статусу, можливість отримання вищої платні, а це також i забезпечення можливостей самореалізації в сфері державного управління, отримання більш змістовної і адекватної професійним інтересам роботи і формування структури неформальних відносин у сфері державної служби і системи влади [15, с. 101].

Стосовно кар'єрного просування державних службовців, можна виокремити два види такого просування:

- вертикальне - просування від меншого рангу державної служби до вищого рівня в ієрархії;

- горизонтальне - просування в межах одного рангу чи категорії, тобто переведення працівника 3 одного робочого місця на інше, задля підвищення його інтересу до роботи.

Законодавством України передбачено умови і процес кар'єрного зростання державних службовців, зокрема, про це йдеться в розділі 5 (ст. 24-29) Закону України «Про державну службу». В цьому розділі зазначається, що просування по службі державного службовця здійснюється шляхом займання більш високої посади на конкурсній основі, крім випадків, коли інше встановлено законами України та Кабінетом Міністрів України, або шляхом присвоєння державному службовцю більш високого рангу [16, с. 490]. Також передбачається, що просуватися по службі в органах державної влади мають державні службовці, які досягли найкращих результатів у роботі, виявляють ініціативу і постійно підвищують професійний рівень.

На думку В.Малиновського, окремих державних службовців цілком задовольняє нинішня посада та вид виконуваної роботи, тому їх не слід орієнтувати на професіональне зростання та кар'єру, але разом із тим, керівник має надати їм інформацію про додаткові можливості, що можуть виникнути у зв'язку 3 підвищенням по службі [12, с. 107].

Перш ніж перейти до факторів, які впливають на розвиток кар'єри, звернемося до закордонного досвіду, де кар'єру розуміють як поступове просування працівника службовими сходинами, зміну кваліфікаційних можливостей, навичок, здібностей і розмірів винагород, пов'язаних із його діяльністю, а пріоритетами в залученні персоналу на державну службу є моральне стимулювання і пошук здібної молоді, яка прагне кар'єрних звершень. Так, наприклад, Сінгапур покращив якість державного апарату за рахунок залучення талановитої молоді, доброго матеріального забезпечення і жорстких заходів проти корупції [17, с. 211].

У США просування по службі для більшості чиновників здійснюється згідно з принципами системи заслуг - відбору найкращих кандидатів на підвищення по посаді на конкурсних іспитах, а також на основі щорічної оцінки їх службової діяльності. В кожній установі державної служби $є$ свій план просування по службі. У випадку, коли на певну посаду немає кандидатів зі своєї установи, оголошується відкритий конкурс [18, с. 145].

Кар'єра французького державного службовця є стабільною та грунтується на переміщеннях за вислугою років і на гарантуванні державному службовцеві зайнятості протягом здійснення кар'єрного просування. Особливістю кар'єрного розвитку французьких управлінців є забезпечення взаємозв'язку 
службового просування та відповідної підготовки. Професійне навчання $є$ необхідною умовою для їх кар'єрного зростання. Призначення на керівні посади будь-якого ієрархічного рівня має супроводжуватися підтвердженням того, що кандидат пройшов чи проходитиме підготовку, пов'язану 3 виконанням ним професійних обов'язків на посаді.

Англійська система просування по службі відзначається жорсткістю на всіх рівнях. Можливості переходу з однієї установи до іншої дуже обмежені. Велике значення традиційно надається старшинству чиновників у міністерській ієрархії, а не їх професійним заслугам. У системі просування по службі німецьких державних службовців є два принципи: підвищення компетенції та послідовне просування від одного ступеня до іншого. Вийнятки у такій системі можливі тільки з дозволу Федеральної комісії по кадрах.

В Україні просування по службі здійснюється шляхом конкурсного відбору, крім випадків, які передбачені законами України. Незважаючи на розбіжність історичних, культурних, економічних умов, закордонний досвід у питанні кар'єри може бути використаний з метою зниження фаворитизму та суб'єктивності нашої державної служби. Для створення ефективної системи управління кар'єрою необхідно виділити ряд чинників і обставин, які впливають на процес кар'єри, а саме:

- соціально-професійні чинники (загальні та спеціальні знання, кваліфікація, професійні здібності, досвід);

- особистісні якості (працездатність, трудова й соціальна активність, орієнтація та установки, соціально-психологічні властивості);

- випадкові обставини (вдалий збіг обставин, походження, добрі стосунки з керівниками);

- демографічні чинники (стать, вік, природні дані).

Фактори, які впливають на розвиток кар'єри державного службовця, можна умовно поділити на зовнішні та внутрішні. Зокрема, до зовнішніх слід зарахувати: урядові вимоги, правову базу, економічні умови, конкуренцію, вимоги до нормативного складу державної установи, місцезнаходження (розташування) державної установи, а до внутрішніх факторів - цілі державної установи, організаційний стиль, професійний характер роботи, технологічні умови, структуру трудового колективу, досвід та стиль керівництва. Аналіз зазначених вище факторів показує, що для планування розвитку кар'єри державного службовця мають значення не самі факти, а їх взаємодія в процесі управління кар'єрою.

Управління кар'єрою включає ряд процесів, а саме: процес планування індивідуальної кар'єри, процес спільного планування кар'єри, організаційний процес планування кар'єри. Процес управління кар'єрою сприяє, з одного боку, підвищенню конкурентоздатності як службовця, так і державної установи, а з другого - потребує наукових підходів до оцінки та використання кар'єрного потенціалу державного службовця державної установи. На жаль, у науковій літературі сьогодні взагалі відсутнє визначення терміна «кар'єрний потенціал». В етимологічному контексті слово «потенціал» має латинське походження і означає «приховані можливості». В словнику іншомовних слів «потенціал» визначено, як «потужність і силу» [19].

В цілому «потенціал» розглядається як «засоби, запаси, джерела, які є в наявності й можуть бути мобілізовані для досягнення певної мети, здійснення плану, вирішення будь-якого завдання; можливості окремої особи, суспільства, держави в певній сфері» [20]. В кінці 80-х років XX ст. в Українському радянському енциклопедичному словнику представлено визначення «потенціалу» як економічної категорії - «...сукупність економічних ресурсів і можливостей..., які можуть бути використані для досягнення цілей соціально-економічного розвитку суспільства» [21, с. 736]. Інакше, - це ступінь можливого прояву будь-якої дії або функції.

Отже, можемо сказати, що науковці розглядають «потенціал» як «можливості/приховані можливості, міць, сила, засоби, запаси, джерела, функції, які можуть бути використані з метою досягнення певної мети».

Якщо говорити про людський потенціал, то він може бути визначений як якості людей, принципово впливаючи на результати активності діяльності, в яку вони залучені. Зважаючи на зазначені вище терміни, під «кар'єрним потенціалом» будемо розуміти приховані можливості, міць та силу державного службовця, які можуть бути використані для забезпечення високої ефективності роботи державної установи та здатність його успішно просуватись службовими сходинками. Для кількісної характеристики «кар'єрного потенціалу» можуть бути використані різні показники залежно від рівня, на якому ця оцінка необхідна.

На глобальному рівні можна використати індекс людського розвитку (IЛР), а на рівні конкретної державної установи - комплексну оцінку конкретного службовця (Ко.дс). Індекс розвитку людського потенціалу (ІРЛП) - індекс для порівняльної оцінки бідності, грамотності, освіти, середньої тривалості життя та інших показників країни. Індекс був розроблений у 1990 році пакистанським економістом Махбубом ель Хаком (Mahbub ul Haq) і використовується з 1993 року ООН в щорічному звіті з розвитку людського потенціалу. При розрахунку ІРЛП враховуються 3 види показників:

- середня тривалість життя при народженні - оцінює довголіття; 
- рівень грамотності дорослого населення країни (2/3 індексу) і сукупна частка учнів та студентів (1/3 індексу);

- рівень життя, оцінений через ВВП на душу населення за паритетом купівельної спроможності (ПКС) в доларах США.

У вітчизняній практиці, зокрема професором Е.М. Лібановою, у розрахунок індексу людського потенціалу покладено вісім складових, що характеризують головні аспекти людського розвитку [23; 24]:

- демографічна ситуація, що є показником і причиною людського розвитку в цілому;

- ситуація на ринку праці, що забезпечує матеріальний добробут населення, можливість розвитку соціальної та виробничої інфраструктури тощо;

- власне матеріальний добробут населення;

- умови проживання населення;

- стан здоров'я населення й охорони здоров'я;

- освіта;

- соціальне середовище (до індексу входять, зокрема, показники, які характеризують криміногенну ситуацію в регіоні;

- фінансування людського розвитку.

Оцінка кар'єрного потенціалу людини (ОКПЛ) досить складна управлінська проблема i в теоретичному і в практичному плані, і на сьогодні не існує універсального підходу до цієї оцінки. 3 огляду на це, пропонуємо використати для оцінки кар'єрного потенціалу державного службовця комплексну оцінку працівника з урахуванням індексу якості «кар'єрної анкети».

Отже, комплексна оцінка держслужбовця (Ко.дс) здійснюється за формулою:

Ко.дс $=[(0,5 \times$ Кп х Дп $)+($ ср х Рр. $)]$ Ія.ка,

де:

- Кп - кваліфікаційно-професійний рівень (освіта, стаж роботи за фахом, активність участі в системі безперервної освіти);

- Dп - ділові якості (рівень морально-психологічного клімату, функціональне навантаження на службовця та індивідуальна продуктивність або рівень ваги в загальному вирішенні питань);

- Ср - оцінка складності функцій (відповідно до функціональних обов'язків рангу чиновника);

- Рр - показники кінцевої оцінки діяльності державної установи (валовий оборот, прибуток підприємств, досягнення високих соціальних показників: зарплата, плинність кадрів, моральне задоволення);

- Ія.ка - індекс якості кадрової анкети (відношення фактичних показників до нормативної моделі, яка забезпечує високу ефективність роботи державної установи).

Досвід застосування такої оцінки в Міністерстві економіки та Міністерстві промислової політики України показав, що комплексна оцінка державних службовців лежить у межах 0,6-0,7 відсотка

$[(0,5$ × 1 × 0,5) + (0,8 × 0,7)] х 0,8 при нормативному значенні 1,0 , а процес планування кар'єри в державних установах як функція або підсистема в управлінні кадрами взагалі відсутня.

Кадрова служба державної установи повинна вміти виявити потреби майбутнього державного службовця, а він сам повинен мати чітку уяву про свої наявні та потенційні можливості, здібності та проявити їх у майбутньому. Тому кар'єра і просування по службі мають будуватись на основі загальної участі обох сторін та їх спільній відповідальності за «свою» частину організації цього процесу.

Планування кар'єри державного службовця передбачає визначення засобів для досягнення бажаних результатів. Відповідальність за виконання планових заходів лежить як на організації, так i на працівникові [5, с. 371]. При цьому керівники підрозділів мають надавати своїм працівникам інформацію про потреби і можливості державної установи (органу державного управління) у кадровому забезпеченні не тільки у межах свого підрозділу, а й по державній установі в цілому.

Висновки та перспективи подальших досліджень. Дослідження, проведене авторами щодо визначення кар'єри, засвідчує універсалізацію підходу до цього визначення і означає поступове просування працівника службовими сходинками, зміну кваліфікаційних можливостей, навичок, здібностей і розмірів винагород, пов'язаних із його діяльністю. Досягнення людини у тому чи іншому виді кар'єри залежить від відповідності між його особистістю та обставинами роботи. Для визначення навичок, якими володіє людина, важливо виявити їі здібності при виборі кар'єри. Методами виявлення здібностей людини, зокрема, є особисті спостереження, анкетування, тестування, вирішення творчих завдань, бесіди, інтерв'ювання, самоаналіз, обговорення. Факторами, які визначають розвиток кар'єри державного службовця, є: бажання зайняти високу посаду, вміння працювати 3 людьми, значний різноманітний досвід керівної роботи, гнучкість до зміни стилю і методів управління, здатність до вироблення нових конкурентноспроможних ідей, висока професійна підготовка, сімейна підтримка, висока психофізична підготовка, уміння орієнтуватись в умовах невизначеності, уміння правильно формулювати думки на великих зібраннях. 
Державний службовець має усвідомлювати кінцеву мету, бачити шляхи до цієї мети, розуміти свій статус як висококваліфікованого спеціаліста, якому держава делегувала свої повноваження та який несе відповідальність за дії, реалізація яких призведе або не призведе до наміченої мети. Для цього державний службовець повинен мати відповідний кар'єрний потенціал, під яким ми розуміємо приховані можливості, міць та силу державного службовця, які можуть бути (і мають бути) використані для забезпечення високої ефективності роботи органу державного управління та здатності його успішно просуватися службовими сходинками.

Для кількісної характеристики кар'єрного потенціалу державного службовця автор пропонує застосовувати систему показників, яка диференційована за рівнями: на глобальному рівні - індекс людського потенціалу; на державному рівні - потенціал пересічного українця; на рівні державної установи - показник комплексної оцінки державних службовців.

Управління кар'єрою - це процес, завдяки якому кар'єра державних службовців керівного складу планується з метою задоволення державних інтересів, носіями яких є державні організації та установи, а також переваг та інтересів кожного окремого держслужбовця. Однак неврахування кар'єрного потенціалу кожного державного службовця призводить до недостатньої ефективності функціонування державної служби України в цілому. В процесі планування кар'єри порівнюються потенційні можливості кар'єрного росту державного службовця 3 вимогами державної установи та розробляється план кар'єрного розвитку конкретного державного службовця і план кар'єрних змін у конкретній державній установі. Досвід показує, що розробка кар'єрних планів $є$ дієвим інструментом підвищення ефективності роботи державних організацій та установ.

\section{Список використаної літератури:}

1. Біскуn В.С. Консультування з питань кар'єри та його складові / В.С. Біскуn. - Тернопіль : ТНЕУ, 2007. - С. 25.

2. Белеикий Н.П. Менеджмент. Деловая карьера / Н.П. Белецкий. - М. : Высшая школа, 2001. - 302 с.

3. Бондар В.Д. Мотивація трудової діяльності державних службовців: Світовий та вітчизняний досвід / В.Д. Бондар // Університетські наукові записки. - 2006. - № 3-4 (19-20). - С. 428-433.

4. Василенко И.А. Административно-государственное управление в странах запада: США, Великобритания, Франция, Германия / И.А. Василенко. - М. : Логос, 2000. - С. 145.

5. Виногородський М.Д. Організація праці менеджера : навч. посібник для студентів економ. спец. ВНЗ / М.Д. Виногородський, А.М. Виногородська, О.М. Шкапова. - К. : Кондор, 2002. - 510 с.

6. Егориин А.П. Управление персоналом / А.П. Егоршин. - 2-е изд. - Н. Новгород : НИМБ, 1999. - 624 с.

7. Економіка України: стратегія і політика довгострокового розвитку / За ред. акад. НАН України В.М. Гейия / Ін-т екон. прогнозування. - К. : Фенікс, 2003. - С. 221-250.

8. Кириченко O.A. Ефективне фінансування вищої освіти - шлях до конкурентної економіки і відкритого суспільства / О.А. Кириченко // Вища школа. - № 4. - 2007. - С. 23-35.

9. Крушельницька О.В. Управління персоналом : навч. посібник / О.В. Крушельницька, Д.П. Мельничук. - К. : Кондор, 2003. - 296 с

10. Маліновський В.Я. Державна служба: теорія та практика : навч. посібник / В.Я. Маліновський. - К. : Атіка, 2003. - $104 \mathrm{c}$

11. Ожегов С.И. Словарь русского языка / С.И. Ожегов ; под ред. Н.Ю. Шведовой. - М. : Сов. энциклопедия, 1973. $-846 \mathrm{c}$.

12. Про державну службу : Закон України від 16.12.1993 р. // ВВР. - 1993. - № 52. - С. 490.

13. Семиволос П. Індекс людському розвитку не завада / П.Семиволос // Дзеркало тижня. - 2001. - № 22 (346).

14. Словник іноземних слів / За ред. член. кор. АН УССР О.С.Мельничука. - К. : Головна ред. УРЕ, 1974. - 776 с.

15. Социальная психология личности в вопросах и ответах : учебное пособие / Под ред. проф. В.А.Лабунской. М. : Гардарики, 2001. - 397 с.

16. Серьогін C. Організація кар'єри державного службовця як засіб попередження і запобігання корупції / С. Серьогін, В.Хлуткова // Вісник УАДУ. - К. : УАДУ, 1999. - Вип. 4. - С. 101.

17. Украинский Советский Энциклопедический Словарь: в 3-х т. Т. 2 / Ред. кол. : А.В. Кудрицкий (ответ. ред.) и др. - К. : Глав. ред. УСЭ, 1998. - 768 с.

18. Управление человеческими ресурсами / Под ред. М.Пула, М.Уоркера. - СПб. : Питер, 2002. - 1200 с.

19. Renge Y. Organizaciju psihologija / Y.Renge. - Riga : Kamene, 2003. - 128 p.

\section{References:}

1. Biskup, V.S. (2007), Konsul'tuvannja z pytan' kar'jery ta jogo skladovi, TNEU, Ternopil', P. 25.

2. Beletskii, N.P. (2001), Menedzhment. Delovaya kar'era, Vysshaya shkola, M., 302 p.

3. Bondar, V.D. (2006), «Motyvacija trudovoi' dijal'nosti derzhavnyh sluzhbovciv: Svitovyj ta vitchyznjanyj dosvid», Universytets'ki naukovi zapysky, No. 3-4 (19-20), pp. 428-433.

4. Vasilenko, I.A. (2000), Administrativno-gosudarstvennoe upravlenie v stranakh zapada: SShA, Velikobritaniya, Frantsiya, Germaniya, Logos, M., P. 145.

5. Vynogorods'kyj, M.D., Vynogorods'ka, A.M. and Shkapova, O.M. (2002), Organizacija praci menedzhera, navch. posibnyk dlja studentiv ekonom. spec. VNZ, Kondor, K., 510 p.

6. $\quad$ Egorshin, A.P. (1999), Upravlenie personalom, 2-e izd., NIMB, N. Novgorod, 624 p. 
7. Gejec', V.M. (ed.) (2003), Ekonomika Ukrai'ny: strategija i polityka dovgostrokovogo rozvytku, In-t ekon. prognozuvannja, Feniks, K., pp. 221-250.

8. Kyrychenko, O.A. (2007), «Efektyvne finansuvannja vyshhoi' osvity - shljah do konkurentnoi' ekonomiky i vidkrytogo suspil'stva», Vyshha shkola, No. 4, pp. 23-35.

9. Krushel'nyc'ka, O.V. and Mel'nychuk, D.P. (2003), Upravlinnja personalom, navch. posibnyk, Kondor, K., 296 p.

10. Malinovs'kyj, V.Ja. (2003), Derzhavna sluzhba: teorija ta praktyka, navch. posibnyk, Atika, K., 104 p.

11. Ozhegov, S.I. (1973), Slovar' russkogo yazyka, in Shvedova, N.Yu. (ed.), Sov. entsiklopediya, M., 846 p.

12. Verhovna Rada Ukrai'ny (1993), Pro derzhavnu sluzhbu, Zakon Ukrai'ny, No. 52, P. 490.

13. Semyvolos, P. (2001), «Indeks ljuds'komu rozvytku ne zavad», Dzerkalo tyzhnja, No. 22 (346).

14. Mel'nychuk, O.S. (ed.) (1974), Slovnyk inozemnyh sliv, Golovna red. URE, K., 776 p.

15. Labunskaya, V.A. (ed.) (2001), Sotsial'naya psikhologiya lichnosti v voprosakh i otvetakh, uchebnoe posobie, Gardariki, M., 397 p.

16. Ser'ogin, S. and Hlutkova, V. (1999), «Organizacija kar'jery derzhavnogo sluzhbovcja jak zasib poperedzhennja i zapobigannja korupcii'», Visnyk UADU, UADU, K., Issue 4, P. 101.

17. Kudritskii, A.V. (ed.) (1998), Ukrainskii Sovetskii Entsiklopedicheskii Slovar', v 3-kh t., Glav. red. USE, K., T. 2, $768 \mathrm{p}$.

18. Pul, M. and Uorker, M. (2002), Upravlenie chelovecheskimi resursami, Piter, SPb, 1200 p.

19. Renge, Y. (2003), Organizaciju psihologija, Kamene, Riga, 128 p.

Загурська-Антонюк Вікторія Францівна - кандидат політичних наук, доцент кафедри економічної безпеки, публічного управління та адміністрування Державного університету «Житомирська політехніка».

Наукові інтереси:

- дослідження геополітичних процесів та процесів політичної децентралізації влади.

E-mail:kgn.zvf@gmail.com.

Березенська Світлана Анатоліївна - магістрант I курсу групи 3ДУМ-18-5м спеціальності «Публічне управління та адміністрування» Державного університету «Житомирська політехніка».

Наукові інтереси:

- дослідження підвищення ефективності роботи державних службовців в Україні.

E-mail: zmi.ecologyzt@ukr.net.

Вовкотруб Тетяна Петрівна - магістрант I курсу групи ЗДУМ-18-5м спеціальності «Публічне управління та адміністрування» Державного університету «Житомирська політехніка».

Наукові інтерес:

- дослідження кар'єрного потенціалу державних службовців.

E-mail: zmi.ecologyzt@ukr.net.

Бондаренко Ольга Вікторівна - магістрант I курсу групи ЗДУМ-18-6м, спеціальності «Публічне управління та адміністрування» Державного університету «Житомирська політехніка».

Наукові інтереси:

- дослідження удосконалення професійного потенціалу державних службовців в органах місцевого самоврядування. 